\title{
Anabases
}

ANABASES Traditions et réceptions de l'Antiquité

$29 \mid 2019$

Varia

\section{Vittorio Alfieri's tormented relationship with Aeschylus: Agamennone between Tradition and Innovation.}

La relation tourmentée de Vittorio Alfieri avec Eschyle. Le cas de son

Agamennone (1783) : entre tradition et innovation

\section{Giovanna Di Martino}

\section{OpenEdition}

Journals

\section{Electronic version}

URL: https://journals.openedition.org/anabases/8704

DOI: 10.4000/anabases.8704

ISSN: 2256-9421

\section{Publisher}

E.R.A.S.M.E.

\section{Printed version}

Date of publication: 14 April 2019

Number of pages: 121-133

ISSN: 1774-4296

Electronic reference

Giovanna Di Martino, "Vittorio Alfieri's tormented relationship with Aeschylus: Agamennone between Tradition and Innovation.", Anabases [Online], 29 | 2019, Online since 14 April 2021, connection on 06 November 2021. URL: http://journals.openedition.org/anabases/8704 ; DOl: https://doi.org/10.4000/ anabases.8704 

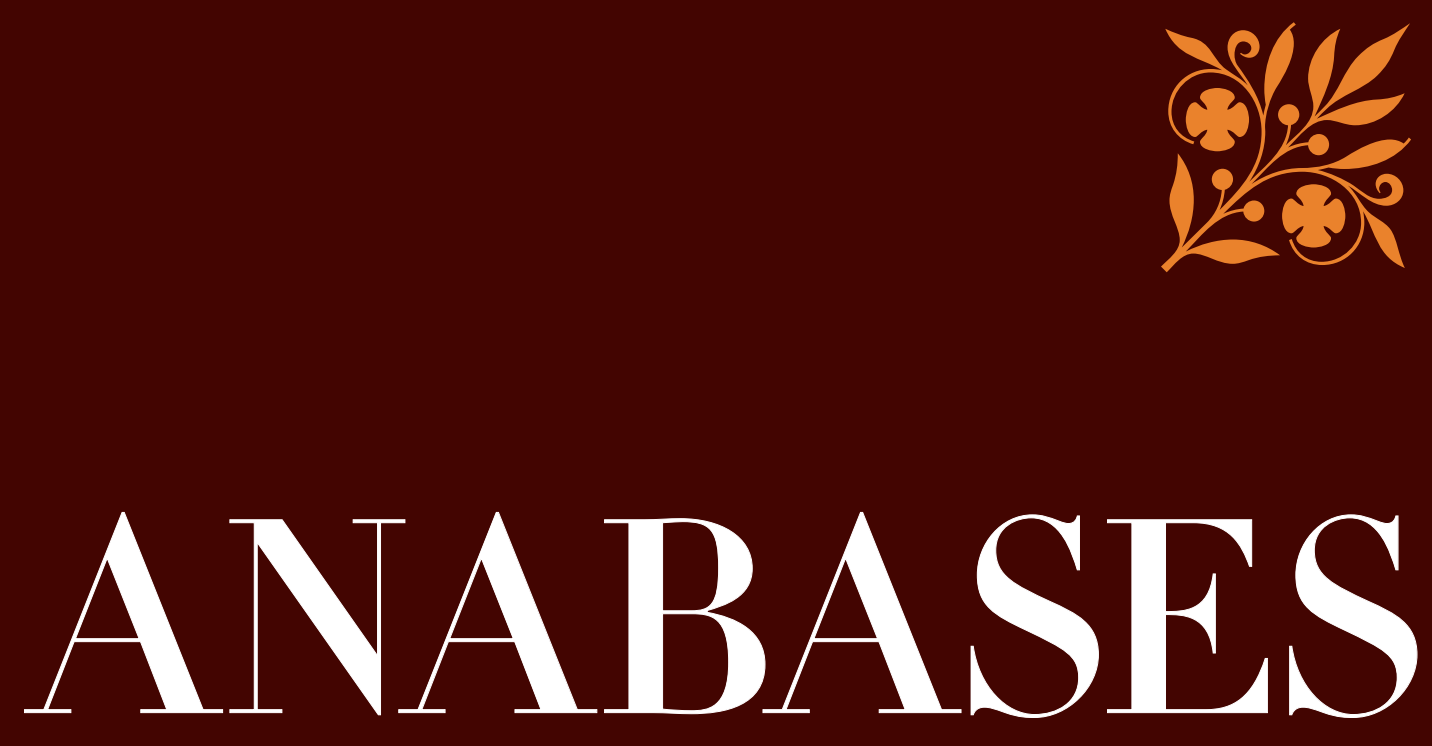

Traditions et Réceptions de l'Antiquité

\section{No29 \\ 2019}

Juliette Ernst Sculptures onctueuses de Meekyoung Shin Théâtre antique et travaux savants dans la Première modernité L'Antiquité dans la peinture (17911880) Réception d'Ovide Pierre Grimal 
ANABASES

Traditions et Réceptions de l'Antiquité

Revue de l'équipe de recherche E.R.A.S.M.E.

Université Toulouse-Jean Jaurès (UT2J)

Anabases dispose d'un Comité de lecture international. Chaque article envoyé à la rédaction est soumis, une fois anonymisé, à l'expertise de deux spécialistes qui rendent un rapport écrit. Les deux rapports anonymisés sont transmis à l'auteur qui tient compte des observations en vue de la publication.

\section{Comité SCIEnTIFIQUe}

Germaine Aujac (université Toulouse-Jean Jaurès : histoire de la géographie et des sciences antiques)

Florence Bouchet (université Toulouse-Jean Jaurès : littérature médiévale)

Hinnerk BruHns (CNRS : histoire économique et sociale ancienne et contemporaine)

Paulo Butti de Lima (université de Bari : historiographie et réception de l'Antiquité)

Luciano CANFora (université de Bari : littérature et histoire anciennes, historiographie)

Giovanna Ceserani (Stanford University : histoire intellectuelle et historiographie de la tradition classique)

Temístocles Cezar (université de Porto Alegre : historiographie moderne)

Serafina Сиомо (University of London, Birkbeck College : histoire des mathématiques et des sciences)

Paul Demont (université de Paris Sorbonne : philologie grecque et héritage classique)

Marie-Laurence Desclos (université de Grenoble II : philosophie de l'Antiquité)

Olivier Devillers (université de Bordeaux 3 - Michel-de-Montaigne : littérature et historiographie latines)

Andrea Giardina (Istituto italiano di scienze umane : histoire du monde romain et de ses réceptions)

Ève Gran-Aymerich (aibl : histoire de l'archéologie et des transferts culturels)

François HaRTog (EHEss : historiographie ancienne et moderne)

Geneviève Hoffmann (université de Picardie : histoire des mondes grecs)

Christian JACOB (CNRS/EHEss : histoire comparée et épistémologie des savoirs)

Suzanne Marchand (Louisiana State University : histoire du classicisme et de l'orientalisme)

Wilfried Nippel (Humboldt Universität Berlin : histoire et historiographie de l'Antiquité)

Sylvie Pittia (université de Paris I-Panthéon Sorbonne : histoire et historiographie du monde romain)

Stéphane Ratri (université de Franche-Comté - Besançon : philologie et héritage latin)

Comité de RÉdaction

Jacques Alexandropoulos, Marielle de Béchillon, Corinne Bonnet, Laurent Bricault, Clément Bur,

Philippe Foro, Adeline Grand-Clément, Anne-Hélène Klinger-Dollé, Véronique Krings,

Thibaud Lanfranchi, Claudine Leduc, Pascal Payen, Grégory Reimond, Catherine Valenti

Éditeur RESPonsable

Pascal PAYen

Université Toulouse-Jean Jaurès (UT2J)

SECRÉTARIAT DE RÉDACTION

Anthony Andurand / Clément Bertau-Courbières / Corinne Bonnet / Clément Bur /

Adeline Grand-Clément / Anne-Hélène Kuinger-Dollé / Véronique Krings /

Catherine Valenti (université Toulouse-Jean Jaurès) / Noémie VillacÈQue (université de Reims)

Sites Web

http://plh.univ-tlse2.fr

Revues.org : http://anabases.revues.org

Aвonnement et vente aU numéro

Éditions De Boccard - 4, rue de Lanneau - 75005 Paris

info@deboccard.com - www.deboccard.com

Tél. : 0033/(0)143260037 - Fax : 0033/(0)143548583 




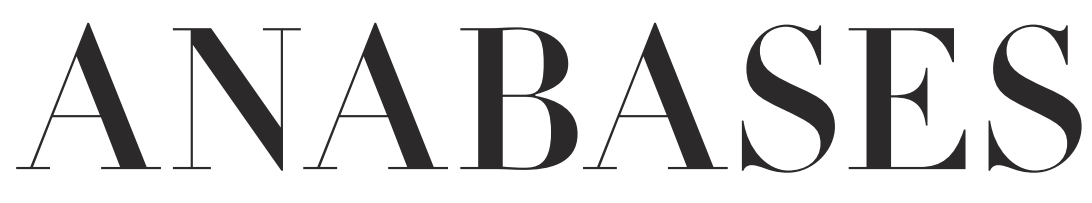

Traditions et Réceptions de l'Antiquité

$$
\begin{aligned}
& N \circ 29 \\
& 2019
\end{aligned}
$$

\section{E.R.A.S.M.E.}

Université Toulouse - Jean Jaurès 



\section{Sommaire}

$\mathrm{N}^{\circ} 29-2019$

\section{Historiographie et identités culturelles}

Ilse Hilbold

Les archives d'une bibliographe des sciences de l'Antiquité :

Juliette Ernst et la fabrique des relations internationales . . . . . . . . . I I3

Vivien LONGHI

La crise, une notion politique héritée des Grecs ? . . . . . . . . . . . 2I

Mireille Lacave-Allemand et Michel Lacave,

L’Antiquité dans la peinture en France, I79I-I880 :

une analyse quantitative à travers les Salons et les Prix de Rome . . . . . 37

Tiphaine Besnard

Du Weathering Project aux autoportraits en Venus :

Les sculptures onctueuses et savonneuses de Meekyoung Shin . . . . . 7 I

\section{Traditions du patrimoine antique}

Dossier dirigé par Pascale Paré-Rey et Malika Bastin-Hammou,

“La réception du théâtre antique dans les travaux savants de l’Europe

de la Première modernité »

Malika Bastin-Hammou et Pascale Paré-Rey

“ La réception du théâtre antique dans les travaux savants

de l'Europe de la Première modernité » . . . . . . . . . . . . . . . . 89

Kevin Bovier

Rétablir la métrique de Térence au $\mathrm{XvI}^{\mathrm{e}}$ siècle :

le cas du Iudicium de Glaréan (1540) . . . . . . . . . . . . . . . . . . . . . . 93 
Brice Denoyer

L'héritage de la métrique antique

dans l'alexandrin français au xvie siècle . . . . . . . . . . . . . IO7

Giovanna Di Martino

Vittorio Alfieri's tormented relationship with Aeschylus:

Agamennone between Tradition and Innovation . . . . . . . . . . . . . . . I2I

Marco Duranti

La condanna del prologo diegetico euripideo dagli scoli antichi

ai trattati del Cinquecento . . . . . . . . . . . . . . .

Rosario López Gregoris

L'influence de l' Arte nuevo de hacer comedias de Lope de Vega

dans l'usage des modèles classiques latins en Espagne

pendant le Siècle d'or et le Baroque » . . . . . . . . . . . . . . . . I49

Cressida Ryan

Sophoclean scholarship as a tool

to interpret eighteenth-century England . . . . . . . . . . . . . . г 6 I

Záviš ŠumaN

Axiologie critique de La Mesnardière . . . . . . . . . . . . . . . . . . . . I79

\section{Archéologie des savoirs}

Dossier dirigé par Cristina Noacco

“2000 ans déjà... Aspects de la réception d'Ovide » . . . . . . . . . . . I93

\section{La réception d'Ovide au Moyen Âge}

Jean-Marie Fritz et Cristina NoAcco

Lire Ovide au xiI ${ }^{\mathrm{e}}$ siècle : Arnoul d'Orléans

commentateur des Métamorphoses . . . . . . . . . . . . . . . $\quad{ }_{195}$

Franck Coulson

Le mythe de Pythagore dans le commentaire

“Vulgate » des Métamorphoses . . . . . . . . . . . . . . . . . . . . . . 2I

Marylène Possamaï

Comment éditer l'Ovide moralisé :

le problème de la mise en page du manuscrit Rouen Bm O.4 . . . . . . . 225

Anneliese Pollock Renck

Les Hérö̈des à la fin du Moyen Âge : pour une définition élargie de l'acte traducteur . . . . . . . . . . . . . . . . . . 239 
II. La réception d'Ovide à l'époque moderne

Fátima Díez Platas et Patricia Meilán Jácome

Le poète dans son œuvre. Ovide dans les images des Fasti

et des Tristia entre les Xv et $\mathrm{xvI}^{\mathrm{e}}$ siècles . . . . . . . . . . . . . . . . . 255

Ana Paula Rebelo Correia

Les représentations des Métamorphoses d'Ovide

dans les azulejos portugais. Influence des modèles gravés français . . . . 269

Sarah ReY

Figures d'Orphée au cinéma . . . . . . . . . . . . . . . . . . . 277

\section{Actualités et débats}

Marine LE BAIL

La modernité littéraire serait-elle affaire d'Antiquité(s) ?

Euvres \& Critiques: La contribution de l'archéologie à la genèse

de la littérature moderne, XLII, I, René Sternke dir., 20I7, 338 p. . . . . . . 2 29I

\section{Lire, relire la bibliothèque des sciences de l'Antiquité}

Éric Morvillez

“Les Horti Tauriani de Pierre Grimal

ou les prémices des Jardins romains » . . . . . . . . . . . . . . . . 30I

Pierre Grimal

“Les Horti Tauriani. Étude topographique sur la région

de la Porte Majeur ",MEFRA, tome 53, rg36. p. 25o-286 . . . . . . . . . . . 3 3i3

\section{L'atelier de l'histoire : chantiers historiographiques}

L'Antiquité au musée (coordonné par Adeline Grand-Clément) (6)

Aurélie Rodes, Catherine Valenti

Les Gaulois au musée . . . . . . . . . . . . . . . . . . . .

355

L'Atelier des doctorants (coordonné par Adeline Grand-Clément) (16)

Andrea Avalli

La question étrusque dans l'Italie fasciste $\ldots \ldots \ldots$. . . . . . . 360 
Droit et réception de l'Antiquité

(coordonné par Marielle de Béchillon et Hélène Ménard) (6)

Entre Clio et Thémis. Entretien avec Dario Mantovani, réalisé par

Hélène Ménard (Maître de Conférences d'Histoire romaine, à l'Université

Paul Valéry - Montpellier III), le 22 juin 20I8, à l'occasion de la parution

aux Belles Lettres du livre Les juristes écrivains de la Rome antique.

Les ouvres des juristes comme littérature (juin 20ı8) et de la création

de la chaire “ Droit, culture et société de la Rome antique »

au Collège de France $\left(\mathrm{I}^{\mathrm{er}}\right.$ novembre $\left.20 \mathrm{I} 8\right) \ldots$. . . . . . . . . . . . .

\section{Comptes rendus}

Philippe Borgeaud et Sara Petrella

Le singe de l'autre.

Du sauvage américain à l'histoire comparée des religions (A. Guedon) . . $\quad 37 \mathrm{I}$

Roberta Casagrande-Kim, Samuel Thrope et Raquel Ukeles (éd.)

Romance and reason. Islamic transformations of the classical past

(Cl. Bertau-Courbières) . . . . . . . . . . . . . . . . . . . . .

Hinnerk BruHns

Max Webers historische Sozialökonomie.

L'économie de Max Weber entre histoire et sociologie (Th. Lanfranchi) . . 374

Andrea Cozzo

Riso e sorriso, e altre saggi sulla nonviolenza nella Grecia antica,

(Fr. Pr. Barone) . . . . . . . . . . . . . . . . . . . 377

Franz Cumont

Manichéisme (St. Ratti) . . . . . . . . . . . . . . . 378

Emmanuelle HÉnin et Valérie NAAs (dir.)

Le mythe de l'art antique (Cl. Evrard) . . . . . . . . . . . . . . . . . 380

Jacques Jouanna, Henri Lavagne, Alain Pasquier,

Véronique SchiLtz et Michel Zink (éd.)

Au-delà du Savoir : Les Reinach et le Monde des Arts (G. Hoffmann) . . . .

382

Mario Liverani

Imagining Babylon: The Modern Story of an Ancient City (C.Bonnet) . . . 386

Françoise-Hélène Massa-Pairault, Claude Pouzadoux (Dir.)

Géants et Gigantomachie entre Orient et Occident (C.Giovénal) . . . . . . .

Scott McGill, Joseph Pucci (éd.)

Classics renewed. Reception and Innovation in the Latin Poetry

ofLate Antiquity (S. Clément-Tarantino) . . . . . . . . . . . . . . . . . . . 
Maxwell T. PAule

Canidia, Rome's First Witch (C. Landrea) . . . . . . . . . . . . . . . . . . . 39г

Jessica Priestley, Vasiliki Zali (éd.)

Brill's Companion to the Reception of Herodotus in Antiquity

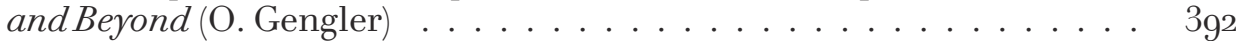

Salvatore QuAsimodo

La Lyre grecque $(\mathrm{M}$. Bianco) . . . . . . . . . . . . . . . . . . 395

Brett M. Rogers, Benjamin Eldon Stevens (éd.)

Classical Traditions in Modern Fantasy (M. Scapin) . . . . . . . . . . . . . 397

Maria Teresa Schettino et Céline UrLacher-Becht (dir.)

Ipse dixit. L'autorité intellectuelle des Anciens : affirmation,

appropriations, détournements (C. Psilakis) . . . . . . . . . . . . . 398

Guy G. Stroumsa

Religions d'Abraham : histoires croisées (D. Lorin) . . . . . . . . . . . . 400

Jean Yvonneau (éd.)

La Muse au long couteau. Critias, de la création littéraire

au terrorisme d'État (G. Hoffmann) . . . . . . . . . . . . . . 405

Résumés . . . . . . . . . . . . . . . . . . . . . 409

Index .............................. 423 



\section{Traditions}

\section{du patrimoine antique}

\section{Dossier dirigé par Pascale Paré-Rey et Malika Bastin-Hammou,}

“ La réception du théâtre antique dans les travaux savants de l'Europe de la Première modernité » 



\section{Vittorio Alfieri's tormented relationship with Aeschylus: Agamennone between Tradition and Innovation.}

Giovanna Di Martino

\section{Alfieri's reception history: Agamennone's and Oreste's entry into the Italian repertoire}

In 1783, Vittorio Alfieri, one of the most prominent cultural figures of eighteenth-century Italy, published his first tragedies, amongst which are both Agamennone and Oreste. ${ }^{1}$ These tragedies, along with those published later, were instantly recognized as revolutionary and original, so much so that they immediately entered the European theatrical repertoire. ${ }^{2}$ Not only had all his

1 See V. Alfieri, Tragedie. Agamennone, ed. C. Jannaco and R.V. De Bello, V Asti, Casa d'Alfieri, 1967; V. Alfieri, Tragedie. Oreste, ed. C. Jannaco and R.V. De Bello, VI, Asti, Casa d'Alfieri, 1967: both are critical editions of Alfieri's tragedies, displaying all the variants from the first (1783) to the second edition (1788), as well as those originating from all extant manuscripts.

2 For a detailed analysis of the reception of Alfieri's tragedies, see W. BInNI, "Vittorio Alfieri", in W. Binni (ed.), I classici italiani nella storia della critica, Florence, Nuova Italia, 1954, p. 193-243; and the exchange of letters between Alfieri and many of the most important scholars of his time (Paolo Maria Paciaudi, Agostino Tana, Giovanni Maria Lampredi, Francois Gabriel La Porte du Theil, Melchiorre Cesarotti, Antonio Bosi, and Girolamo Tiraboschi), collated in V. Alfieri, Parere sulle tragedie e altre prose critiche, ed. M. Pagliai, Asti, Casa d'Alfieri, 1978. As Tiraboschi rightly noticed, "so strong a reaction would not have been stirred had Alfieri's tragedies lacked any merit, especially such a distinctive one" (Alfieri, Parere, p. 537). Henceforward, translation 
plays been translated into French, German, English and Spanish and been widely performed by the first decades of the nineteenth century, but his politically oriented plots, highlighting the clash between tyrannical power and individual freedom, heavily influenced opera, as well as dance performances. ${ }^{3}$

As a matter of fact, Alfieri's Agamennone and Oreste informed Onorato Viganò's and Francesco Clerico's famous ballets revolving around Agamemnon's death and Orestes' revenge. ${ }^{4}$ And if in 1775 , after a performance of Jean-Georges Noverre's Agamennone vendicato at the Royal Ducal Theatre in Milan, the local newspaper could claim that a programme of the ballet was needed because the "audience had never heard of Clytemnestra or Orestes, neither did they know who Agamemnon, Aegisthus or Electra were", this was certainly not the case ten years later, when Clerico's and Viganò's dance performances of their Agamemnon and Orestes were acclaimed by an audience which was now well-versed in the story, thanks to Alfieri's tragedies. ${ }^{5}$

of Italian scholarship is mine; for Alfieri and Brumoy, I have retained the original text, with no translation.

3 On the influence of Alfieri's tragedies on opera, see A. SAcchetri, "L'arte musicale intorno ad Alfieri: realtà del suo tempo e riflessi creativi", in G. Tellini and R. Turchi (eds.), Alfieri in Toscana: atti del Convegno internazionale di studi, Firenze, 19-20-21 ottobre 2000, Florence, Olschki II, 2002, p. 781-803, 795-803. Alfieri's Oreste in particular was translated and used in other countries as well for patriotic purposes: in Germany, Spain, Portugal, and even in Brazil, Oreste played a most important political role before suddenly disappearing (cf. A. PARducci, "Traduzioni spagnole di tragedie alfieriane", Annali Alfieriani I, Asti, Casa d'Alfieri, 1942, p. 31-152; and G.C. Rossi, "L'Alfieri e il Portogallo", Annali Alfieriani I, p. 153-188). For a detailed account of Alfieri's reception in England, see J. Lindon, "Appunti sulla ricezione inglese dell'Alfieri nella prima metà dell'Ottocento", in R. Cotteri (ed.), XXIII Simposio internazionale di studi italo-tedeschi: Vittorio Alfieri, il poeta del mito, Merano, Accademia di studi italo-tedeschi, 2002, p. 64-75; in France, see C. Del Vento, "La première réception d'Alfieri en France: une fortune controversée", Lettres italiennes en France 11 (2005), p. 53-68.

4 These are ballets by Clerico and Viganò drawing on the Orestes-Electra and Agamemnon-Clytemnestra myths and especially influenced by Alfieri's retelling of the Oresteia: Viganò's La morte d'Egisto ossia le Furie d'Oreste (1794) and Clerico's Il ritorno di Agamennone (1789), the latter a ballet performed again in 1793, in 1794 under the title La morte di Agamennone and in 1801 under the title Agamennone. For Onorato Viganò, see S. Onesti, Di passi, di storie e di passioni. Teorie e pratiche del ballo italiano nel secondo Settecento Italiano, Turin, Accademia University Press, 2016, p. 164-183, and R. Zambon, "Il Settecento e il primo Ottocento", in J. Sasportes (ed.), Storia della Danza Italiana dalle origini ai giorni nostri, Turin, EDT, 2011, p. 137-141; for Francesco Clerico, see Onesti, Di passi, p. 184-211.

5 S. Onesti, "Autorialità e autorità del libretto di ballo del secondo Settecento: 
And if Alfieri's Oreste has enjoyed a widespread appreciation especially on the stage, his Agamennone has always intrigued the scholarly world for its evident ties with Seneca's homonymous tragedy, which critics have tended to recognize as Alfieri's major source. ${ }^{6}$ However true this might be on a superficial (and linguistic) level, I will argue that Aeschylus' Agamemnon, via the highly influential writings on Greek tragedy of the French Jesuit Pierre Brumoy, played as essential a role in the creation of Alfieri's masterpiece as did Seneca.

One important factor when looking at Alfieri's tragedies, and at his Agamennone in particular, is the question of sources, not to engage in 'source spotting' as such, but more broadly in order to uncover the weave of memories that has embroidered this tragedy. In other words, I am interested in what Alfieri 'remembered' or 'misremembered', perhaps, and what he appropriated in order to create his play.

\section{A primitive theatre: Aeschylus, Brumoy and Alfieri's Oresteia}

It was in the summer of 1775, during Alfieri's sojourn at Cesana, on the border with France, that Alfieri supposedly read the 1730 edition of Pierre Brumoy's Théâtre des Grecs, a text that has been recently reinstated to the canon of the most influential sources on the reception of ancient drama in eighteenth-century Europe. ${ }^{7}$ Alfieri had the chance to read not only Brumoy's "analyses raisonnées"

problematiche e prospettive di studio", Danza e Ricerca. Laboratorio di studi, scritture, visioni $\mathrm{V}$ (4) (2013), p. 22.

6 For a detailed account on the reception of Alfieri's Oreste, see C. Montano, "La fortuna teatrale dell'Oreste di Alfieri nel Novecento", Il Platano XXIII (2) (1998), p. 112-152. On his Agamennone, see, amongst others, C. Domenici, "Seneca nel giudizio di Alfieri: poeta magnus o declamatory?", in G. Tellini and R. Turchi (eds.), Alfieri in Toscana. Atti del Convegno Internazionale di Studi. Firenze, 19-20-21 ottobre 2000, II, Florence, L. S. Olschki, 2013, p. 451-490; C.F. Goffis, "Agamennone. Contributo allo studio parallelo di L. Anneo Seneca e V. Alfieri”, Paideia LIII (1998), p. 177-207; E. Paratore, "L'Agamemnon di Seneca e l'Agamennone dell'Alfieri", in W. Binni (ed.), Letteratura e critica. Studi in onore di Natalino Sapegno, I, Rome, Bulzoni, 1974, p. 517-556; V. Perdichizzi, "Il modello francese nelle tragedie senecane di Alfieri", Revue des études Italiennes 50 (2004), p. 87-118; and A. Traina, "Alfieri traduttore di Seneca", in I. Dionigi (ed.), Seneca nella coscienza dell'Europa, Milan, Mondadori, 1999, p. 235-261.

7 Cf. C. Sensi, Quattro studi filologici, Montpellier, Université Paul-Valéry, 1990, p. 41. On Brumoy's influence on eighteenth- and nineteenth-century European drama, see Anabases: Traditions et réceptions de l'Antiquité 14 (2011) and the coordinator's introduction to the whole issue: M. Bastin-Hammou, "Introduction. Brumoy, pédagogue et passeur du théâtre grec", Anabases, 14 (2011), p. 27-41. Alfieri could read Greek only from 1795; however, neither the plots of some of the Greek tragedies nor some of the Latin translations of these (even if the latter were impossible to track 
of Aeschylus' plays, but also the Jesuit's detailed essays on ancient theatre more generally. Brumoy's invitation to his reader "à devenir Athénien"; to let go of modern preconceptions in order to appreciate fully the aesthetics of ancient theatre; his insistence on the simplicity, even naivety of Greek theatre, "toute semblable à l'action réelle"; his praise of Aeschylus' "mouvements naturels", of the dominance of action over words and of passions and sentiment over discourse - all of these clearly left an indelible trace in Alfieri's memory, the originality of whose works is built precisely on this idea of primitive theatre. ${ }^{8}$

Alfieri's return to this primitive theatre was absolutely in line with the programme of the Academy of Arcadia, a literary academy established in Rome in 1690, with the programmatic intent of clamping down on the baroque, exuberant, extravagant modes of making poetry and doing theatre, and of returning to the classics as Italian tragedy's only source. The thoroughness with which the Arcadians had taken up the reading and interpretation of the classics - and of Aristotle's Poetics in particular for tragedy - was directed towards renewing Italian literature following the spirit of the ancients, a "restoration of the civic ideals regained within the classics", as has been argued. ${ }^{9}$ In translating the classics especially, such "a yearning for a return to nature" was embedded within the

down) were unknown to him before that: he informs us of this himself when - in his autobiography - he affirms that alongside Seneca's tragedies, he was also reading "traduzioni letterali latine dei Tragici Greci", which he found more faithful and less tedious than the Italian translations available to him (V. Alfieri, Vita scritta da esso, ed. L. Fassò, Asti, Casa d'Alfieri, 1951, p. 189). In terms of adaptations, on the other hand, although only the thirteen-volume edition of Brumoy's Théâtre des Grecs (17851789, expanded by André-Charles Brotier; see C. Del Vento, “'Io dunque ridomando alla Plebe francese i miei libri, carte ed effetti qualunque'. Vittorio Alfieri émigré a Firenze", in G. Tellini and R. Turchi (eds.), Alfieri in Toscana, p. 491-578, 567) appears in his Parisian library, it is certain that he had access to Brumoy's summaries of Aeschylus' tragedies (1730); once again, he provides us with the necessary information when explaining the source for his Polinice: "nel Polinice l'avere io inserito alcuni tratti presi nel Racine, ed altri presi dai Sette Prodi di Eschilo, che leggiucchiai nella traduzione francese del padre Brumoy" (Alfieri, Vita, p. 195). Since he was referring to events taking place in 1776 , he could only have been referring to the 1730 edition, which, however, did not contain any translations of Aeschylus' tragedies, but only abridged and summarised versions of them.

8 Cited in C. Lechevalier, (2011), "L'imaginaire de la représentation dans Le Théâtre des Grecs de Brumoy (1730)", Anabases 14 (2011), p. 75-86, 76, 77, 80.

9 C. Fanti, Teorie della traduzione nel Settecento italiano: note e discussioni, Bologna, Compositori, 1980, p. 5. For Aristotle's influence on eighteenth-century classical tragedy, see, amongst others, L. Muratori, Della perfetta poesia italiana, Modena, 1706; V. Gravina, V., Della tragedia, Naples, 1715. 
programmatic intent of re-establishing the supremacy of Italy as the country of "lettere" through the classics. ${ }^{10}$

Alfieri's theatre, then, perfectly in tune with the Arcadian manifesto and its polemic against baroque mannerism, was a theatre of reform: this reform entailed a drastic reduction in the number of characters, an elimination of confidants, and a reduction of the action to a single subject, to what was understood at its heart to be the conflict in ancient drama - tyranny versus individual freedom. "Pensa coi classici", says Alfieri in one of his works, echoing Brumoy's prescriptions, "coll'intelletto e coll'anima spazia se il puoi, infra Greci e Romani; scrivi, se il sai, come se da quei grandi soli tu dovessi essere letto; ma vivi, e parla, co' tuoi"."

Alfieri shares with Brumoy a twofold attitude towards the ancients: on the one hand, it is necessary to become one with them; on the other, however, they are both well aware of the intrinsic impossibility of getting away from their own time and that they are presenting the ancients to contemporaries. This is why Brumoy provides his analyses of ancient tragedies alongside detailed comparisons with the modern dramas they inspired, always trying to find reasons for specific theatrical choices; this is also why Alfieri is in constant dialogue with his contemporaries, whom he involves in public readings of his tragedies, where he challenges scholars from the Arcadia to judge them from a theatrical perspective, using theatrical criteria. $^{12}$

\section{Alfieri's Clytemnestra: from the androgynous Aeschylean queen to the fluctuating Senecan lover}

Such a twofold attitude is especially evident in the creation of one the most intriguing figures of eighteenth-century drama: Alfieri's Clytemnestra, a character that gradually changes as Alfieri goes through the so-called "tre respiri" ("three breaths": "idea", "stesura", and "verseggiatura"), the three stages comprising his creative process. ${ }^{13}$ Although Alfieri only meant the final "breath", the "verseggiatura", to be read by his audience, the critical editions of his tragedies conveniently report all three versions of the text, thus allowing to keep track of the (intellectual and linguistic) changes from the very first draft to the last.

10 Fanti, Teorie, p. 5.

1 V. Alfieri, La virtù sconosciuta, ed. A. Di Benedetto, Turin, Fògola, 1991, p. 58-61.

12 To those who criticized Alfieri's harsh verse, Alfieri answered that the ultimate judge of the effectiveness of his lines wuold be his audience's, for he wrote his tragedies to be acted out, not read (cf. Alfieri, Parere, p. 275, 459).

13 Cf. Alfieri, Vita, p. 201-202. 
Clytemnestra "ondeggi sempre", Alfieri says in the "idea". ${ }^{14}$ Her continuing vacillation between her love for Aegisthus and her duties as a parent and wife is, in fact, the hallmark of her character, as in Seneca. Yet, as said, her instability and fluctuations are only gradually revealed and enhanced as her characterisation undergoes several mutations during the 'three breaths' of Alfieri's creative process.

An example of this is Act I, scene iv, a scene wholly devoted to Agamemnon's return and his interaction with the queen and Electra. The scene is all but absent from Seneca's play (in which Agamemnon is very much in the background, his presence being relegated to less than thirty lines, 782-807), but more elaborated in Aeschylus' play, save in the case of Electra who does not appear. In Alfieri's "stesura", the queen is questioned about her alleged distress and uncertainty by the king, to whom, at first, Electra responds with an account of the different rumours they have heard regarding his shipwreck; thereafter the queen herself utters:

Clit. Signor mi mancano i detti ad esprimerti ciò ch'io sento nel core: esprimerti, ridirlo non può lingua umana. Lascia che un cotal poco io mi riabbia, non si può dal dolore alla gioja passare in un punto. Mille, e mille son le cose che dirti vorrei, eppur nessuna ne trovo onde principiare. Agli Dei fia necessario di correr ben tosto a ringraziarli dell'inaspettato tuo arrivo; a pregarli di conderne d'or innanzi più felici giorni; più stabil pace, più sicura quiete. ${ }^{15}$

Clytemnestra seems here to have rationally decided to cover up her clear disappointment at Agamemnon's return by launching into him with all she has suffered during his absence.

Some linguistic similarities in this speech to Brumoy's summary of A. Ag., 855905, would suggest that it provides Alfieri's subtext for this passage. It is "un assez long discours", as Brumoy describes it, wherein Clytemnestra relates how she had to endure "solitude, bruits sachez, nouvelles affligeantes, alarmes continuelles" (cf. A. Ag., 861-65), even to the extent that "elle a même attenté plus d'une fois sur la vie, que des secours cruels lui ont conservée”. Agamemnon's “imprévu” return, though, has now washed away all her sufferings. ${ }^{16}$ The shift between "dolore" and "gioia", hinted at by Electra's preceding speech too, resonates with the agitated description of contradictory news and alarms in Brumoy; and Agamemnon's

14 Alfieri, Agamennone, p. 88. Henceforward, I will quote page numbers for anything that is not Alfieri's published final version of the tragedy, which I will reference with act, scene, and line numbers instead.

15 Alfieri, Agamennone, p. 109.

16 P. Brumoy, (1749), “Agamemnon d'Eschyle”, in P. Brumoy, Le théâtre des Grecs, Paris, Robustel, p. 280-310, 294-95. 
"inaspettato" return also recalls Brumoy's "imprévu", which Aeschylus never qualifies as such in his play. The final version shrinks the whole passage into an eloquent and muttered "Io mesta?" (II, iv, 247) followed by suspension points - an almost obsessively recurring stylistic choice.

Agamemnon's reaction to Clytemnestra's behaviour in the "stesura" is plain and reasonable: once alone with his daughter, he inquires into the "visi taciturni e immoti, tremanti" of his people, and, above all, about his wife, "incerta e confusa". She seems to him to have spoken "composte parole", "studiati pomposi detti". ${ }^{17}$

These polished (and deceitful) words that Agamemnon rebukes his wife for, or, as in the final version, the "composti studiati accenti" (III, i, 26) are taken directly from Brumoy's "manières étudiées", which Agamemnon is reported to have detected in Clytemnestra. ${ }^{18}$ The expression "studiati accenti" occurs again after Agamemnon has surrendered to Clytemnestra and agrees to walk on the red carpet, yielding victory to his wife: this battle, Brumoy comments, is "de politesse affectée"; and yet, when Agamemnon exhorts the queen to treat Cassandra as her equal, she responds "avec son affectation ordinaire" (and Brumoy continues to summarise lines 958-960). ${ }^{19}$ Brumoy's insistence on this "affectation" must have been inferred both from the Aeschylean chorus' repeated allusions to "disaffected citizens of Argos who may pretend to welcome $<$ Agamemnon $>$ warmly but are really his enemies", as Sommerstein points out (A. Ag., 787-798), and the king's answer to this precise warning (A. $A g ., 832-840) .{ }^{20}$ While Aeschylus' passage only implies any reference to Clytemnestra's behaviour through tragic irony, Brumoy explicitly links it with the queen. ${ }^{21}$

These "affected" words are also translated into another dialogue that has been heavily reworked as part of Alfieri's creative process. This occurs in Act III, scene iv, after Agamemnon has discovered that Aegisthus now resides in the palace and has granted him one day to leave. In the "stesura", Clytemnestra addresses Agamemnon as "sposo", - later changed to "signor", in a more distant and cold

17 Alfieri, Agamennone, p.110.

18 Brumoy, Agamemnon, p. 297, 296.

19 Ibid., p. 298.

20 Aeschylus, Aeschylus, ed. \& transl. A. H. Sommerstein, II, Cambridge and London, Harvard University Press, 2008, 90.

21 Agamemnon's rather direct speech in response to Clytemnestra's open invitation to step on the red carpet might also be a reference point for Brumoy's "affectation"; however, in Aeschylus the king stresses the unsuitability of a man to be praised like a god, especially by a woman; the deceitfulness of Clytemnestra is implied in the request, but explicated, albeit not directly referring to her, only by the chorus and Agamemnon beforehand (the whole play is in a way an unfolding of hints at Clytemnestra's artificial behaviour; Aeschylus begins to drop them from the start, A. Ag., 18-19). 
manner - and urges him to meet with the citizens and sacrifice in thanksgiving to the gods. ${ }^{22}$ Hence, when Agamemnon told her that he would have appreciated it if she had informed him of Aegisthus' presence in the palace, Clytemnestra rationally explains that she did not believe it important. In the final version, instead, Clytemnestra utters disconnected words, imbued with the now familiar ellipses that reveal her clear reticence: "Signor,... fra tue tant'altre cure... / io non credea, ch'ei loco..." (III, iv, 266-267). But there is more: when Agamemnon enquires whether Clytemnestra would beg for Aegisthus' mercy, the "stesura" reports this interesting exchange of lines between the two:

Clit. Io per lui pietà? E vuoi ch'io t'insegni a Regnare? Che altro può far Clitennestra se non approvare quanto fai; se non contribuire per quanto è in sua possa alla tua massima felicità?

Ag. Al Trionfo dunque m'avvio; ma non crediate già che Agamennone insuperbito per la vittoria obbliar possa le umane vicende. ${ }^{23}$

Not surprisingly, Clytemnestra's deceiving words disappear in the final version as does Agamemnon's eloquent answer.

In addition to being another instance of those "studiati accenti", on which Alfieri plays, the passage seems a direct reaction to the Clytemnestra-Agamemnon dialogue in the tragedy of Aeschylus, who, as I will demonstrate, Alfieri grapples with in a sort of imaginary agon, as much as he does with Seneca. Clytemnestra, in order to be credible in the eyes of Alfieri's contemporaries, is in no position to suggest to her king how he should rule, as she does in Aeschylus; in fact, the warning of Agamemnon's people, in Alfieri, that he should keep his hubristic behaviour in check needs to be read in opposition to the Aeschylean king acceding to his wife's requests.

Clytemnestra's first response to Agamemnon, Brumoy writes, marks well "la caractère dangereux de Clytemnestre prête à tuer son époux" as well as "l'art infini d'Eschyle à faire parler ses personnages conformément à leurs passions même caches". ${ }^{24}$

22 It is interesting that she mentions the obligation to sacrifice again, exactly as she did when Agamemnon returned; the passage in the "stesura" is, in fact, a Romanised version of the chorus' description of Clytemnestra's setting up the sacrifices all over the palace, once she heard the good news of Troy taken (cf. A. Ag., 84-96, which is reported thus in Brumoy's Agamemnon: "les autels, dit le Vieillard, sont parfumés de libations; les lampes brillent de feux", Brumoy, Agamennon, p. 284): "i sacri altari / fuman d'incenso già: di fior cosperse / le vie, che al tempio vanno" (III, iv, 256-8). In the "stesura", "il carro trionfale" was part of the picture too (Alfieri, Agamennone, p. 113). Alfieri, Agamennone, p. 114.

24 Brumoy, Agamennon, p. 296. 
Agamemnon's attempt to refuse his wife's ostentatious welcome, on the other hand, portrays "le contraste d'une femme détestable, ou plutôt d'une Furie avec un Roi pieux \& populaire". ${ }^{25}$ Whether this is the Aeschylean Agamemnon that modern commentators would recognise, Alfieri's Agamemnon is indeed a pious and popular king. Yet, Brumoy explains how the carpet scene prepares the audience "à concevoir de la compassion pour l'un", Agamemnon, and "de l'horreur pour l'autre”, Clytemnestra. ${ }^{26}$ Brumoy's account of Aeschylus' depictions of Agamemnon and Clytemnestra, however overly simplistic, is clearly meant to enhance Clytemnestra's wickedness over a faultless Agamemnon, even though, as he states, Aeschylus' skill is in progressively guiding the spectator through a succession of "artifices". ${ }^{27}$

On the other hand, Alfieri eventually strips Clytemnestra of the traits of the androgynous Aeschylean queen and carves out a character who arouses both "compassion" and "horreur" in the spectator, to adopt Brumoy's reading of Aristotle's terms. Alfieri himself, when reasoning over his own play, acknowledges the complexity of emotions that, in the end, Clytemnestra succeeds in stirring: depending on whether the spectator believes in the force of fate that instils crazed passions in human beings, or whether he or she assesses her character in ethical terms, Clytemnestra will be either pitied or despised. ${ }^{28}$ And, as always in his agonistic relationship with Aeschylus, the Greek model is essential to creating Alfieri's own Clytemnestra.

Part of Clytemnestra's mutation throughout the various creative stages also affects her behaviour towards Agamemnon. In Act III, scene VI, of the "idea", for example, Alfieri writes that Clytemnestra "tenta di sollevare Elettra contro del Padre, tacciandolo di crudele e d'orgoglioso, e d'aver sacrificata Ifigenia sua sorella". ${ }^{29}$ While Iphigenia's murder will remain a constant in Clytemnestra's motives to murder her husband, her attempt to turn Electra against her father disappears from the "verseggiatura". Agamemnon is in fact depicted in a way that would not allow any accusations of cruelty or arrogance. The pious leader of the Greeks is impeccable from the start: in his first dialogue with Electra and Clytemnestra when he returns (II, iv, 222-247), he is the one to bemoan Iphigenia's death as an ill-fated burden inflicted upon him, from which he has suffered since it happened. Agamemnon's involvement in Iphigenia's sacrifice is smoothed out: Alfieri's king seems almost without fault, and is therefore hard to hate.

\footnotetext{
25 Ibid.

26 Ibid., p. 296-297.

27 Ibid.

28 Alfieri, Parere, p. 97-98.

29 Alfieri, Agamennone, p. 88.
} 
In this regard, it is interesting to look at the various stages of Clytemnestra's final decision to murder him. Neither in the "idea" nor in the "stesura" is it necessary for Aegisthus to mention Cassandra as an incentive for her to act against Agamemnon, as in Seneca (Sen. Ag. 254-59). The prophetess does not even make an appearance in the "idea", while in the "stesura", Aegisthus eventually brings her up, but only after Clytemnestra has already planned to kill her "aborrito and crudele marito" ${ }^{30}$ In the "verseggiatura", however, Alfieri feels the need to insert her as a motive for Clytemnestra's resolution. The queen's utterance "Atride pera" comes after Aegisthus has insinuated that Cassandra has come to steal Clytemnestra's place and become queen, closely retracing Seneca's narrative (IV, i, 129-132). ${ }^{31}$

If, however, the Cassandra motive does play a role in Clytemnestra's decision at this point in the plot, it soon becomes completely meaningless due to Agamemnon's clarification of the matter. In Act IV, scene 4, Agamemnon directly asks Clytemnestra to reveal the source of her pain to him, and, believing that it is Iphigenia's death, for which she has never forgiven him, he begins to defend himself, whereupon the queen suddenly changes the topic and confesses how it is Cassandra that makes him less sympathetic in her eyes. To which Agamemnon replies that she can have her, only:

Ti voglio

Sol rimembrar, ch'ella è di re possente

Figlia infelice; e che infierir contr'essa

D'alma regal saria cosa non degna (IV, iv, 269-283).

Agamemnon exhorts Clytemnestra to treat Cassandra, "figlia infelice", according to her royal station ("d'alma regal"), which Alfieri derives from Brumoy's "il rehausse le mérite de cette Princesse malheureuse qui était fille de Priam". ${ }^{2}$ Agamemnon pities Cassandra's fate and warns Clytemnestra how shameful it would be if she raged against her, a warning that closely retraces A. Ag., 951-952, fully translated by Brumoy in his version. ${ }^{33}$

Alfieri, little by little, rules out all the possible superficial motives that lead Clytemnestra to the act of murder, only to enhance the sole, main reason that has driven her throughout the tragedy: her crazed love for Aegisthus, as important as in Aeschylus' play. Even Iphigenia's death takes second place in her interior battle: it is left out when the queen resolves to stab Agamemnon during the night.

30 Alfieri, Agamennone, p. 118. Both adjectives disappear from later versions.

31 See also Ibid., 235.

32 Brumoy, Agamennon, p. 298.

33 Ibid., p. 297-298. 
Iphigenia may indeed represent the first cause of which Clytemnestra developed a strong hatred for Agamemnon (II, i, 95-111), but ultimately it is the fear of losing Aegisthus that spurs her on in her evil plan. Her soliloquy just before the assassination explains this very well, when she endeavours to find fault in Agamemnon, yet realises that his only fault is being married to her:

Delitti invan ti appongo: ah no, non ami

Cassandra tu: più ch'io nol merto m'ami;

E sola me. Niuno hai delitto al mondo,

Che di essere mio consorte (V, i, 14-17).

If she was about to back down on the murder, it is only because she worries lest even Aegisthus despise her for that "atrocidate immense" (IV, i, 12) that she has promised to commit. In the end, decisive in her final resolution is Aegisthus' lie about how Agamemnon has discovered their affair and ordered his death, in response to which Aegisthus declares that he will commit suicide if she does not kill Agamemnon. The thought of her lover's death alone eventually pushes her to commit the murder. "Necessario è il delitto" (V, ii, 117), she utters, and "amor" will give her the strength, Aegisthus reassures her (V, ii, 118-119).

In a frantic and broken speech that takes place after her husband's death, she begins to comprehend what she has done:

... Gronda il pugnal di sangue;... e mani, e veste,

e volto, tutto è sangue... Oh qual vendetta

di questo sangue farassi!... già veggo,

già al sen mi veggo questo istesso ferro

ritorer,... da qual mano!... Agghiaccio,... fremo,...

Vacillo... Oimè!.. forza mi manca,... e voce,...

E lena... Ove son io?... che feci?... Ahi lassa!... (V, iv, 154-160).

There is no trace of the Aeschylean cruelty in the exultation in the crime, nor of Seneca's queen, who then turns to Electra to complete her mission. Rather, when a triumphant Aegisthus joyfully utters that Orestes will be next, Clytemnestra murmurs:

Oreste?... oh cielo! Or ti conosco, Egisto... (V, vi, 172).

Now she has finally come to "know" him, recognise him for who he is. The verb is of incredible linguistic power in that it eventually unveils Clytemnestra's blindness, which has been a recurrent motif in the tragedy, taking the Senecan caeco amore (Sen. Ag., 118) to the extreme. ${ }^{34}$ Although fully aware of the "impurity" of

34 Electra repeatedly accuses her mother's sight of being occluded by an irrational 
this flame ("impura fiamma"; II, i, 68), she cannot but follow it: she is enslaved to it. She "knows" that it will lead to self-destruction, yet - when she sees in Electra the ultimate obstacle to pursuing the realisation of her love - she begs her to leave her alone, "co' pensieri miei, con la funesta fiamma / che mi divora" (III, v, 319-320). Clytemnestra's entrapment within an irrational, irresistible force represents one of Alfieri's major achievements throughout the various creative stages.

Alfieri's originality lies in the subtle (and rather modern) transformation of the major role played by fate in his ancient sources into an inner force that guides Clytemnestra to perform what she would not choose, but is nonetheless doomed to commit. Alfieri's Agamemnon is not as much about the dichotomy between a tyrannical power and the striving for freedom, as are many of his plays, which probably accounts for its poor reception history until very recently; rather, it is about the complete defeat of human willpower. Indeed, the gods make their appearance in the play, but as puppets themselves of the actual puppeteer, namely Clytemnestra. ${ }^{35}$ She is true to her lineage because she willingly decides, yet she knows the self-destruction that will ensue. Clytemnestra starts off as an Aeschylean-like queen, only to soften gradually under the Senecan sway, and eventually to emerge as that rational because conscious, yet equally irrational, persona who not only Electra, but the reader/spectator too, feels the need to exonerate.

\section{Alfieri's legacy to Italian theatre}

Neither Aeschylus' Agamemnon nor his Choephori received many translations in the eighteenth and nineteenth centuries in Italy. As a matter of fact, Agamemnon, translated for the first time in 1796, received only two translations in the nineteenth century, while Choephori, translated for the first time in 1821, had to wait until the first decade of the twentieth century to be taken up again for translation. ${ }^{36}$ And if translations of these two Aeschylean plays were scant indeed, their presence on the stage was almost non-existent: the Oresteia was performed for the first time in

passion: "amor t'acceca" (I, iii, 211) are the words that burst out from her mouth, revealing how she knows about her and Aegisthus; "accecata madre" (II, ii, 95) is what she calls her, knowing that Aegisthus is only exploiting Clytemnestra's love.

If Alfieri's Agamennone counts no more than seven performances in the eighteenth and nineteenth centuries, from the 1950s to the present it has been staged eight times, beginning with Orazio Costa's production in 1952 and ending with Marco Viecca's in 2017 in Asti.

36 Cf. G. Marotti, L’Agamennone, Rome, Nella Stamperia Salomoni, 1796; F. Bellotti, Tragedie di Eschilo, tradotte da Felice Bellotti, Milan, Della Società tipografica dei classici italiani, 1821; T. Marrone and A. Cippico, Eschilo. L'Orestea, Rome, 1904. 
1906, but it was only in 1914 with the Agamemnon and in 1921 with the Choephori, both staged at the ancient theatre in Syracuse, that a scholarly translation of part of the Oresteia was put on stage. ${ }^{37}$

Instead, productions of Alfieri's Agamemnon, and Oreste in particular, were the sole on-stage representatives of Aeschylus' Oresteia for more than a century. One of the reasons for their immediate entry into the Italian canon was their powerful retellings for a modern Italian audience, in that particular neo-classical form that became the new 'regular' tragedy after Trissino's Sofonisba in the sixteenth century. If by the 1820s Alfieri's tragedies had completely disappeared from the European repertoire and remained only in the Italian one, it was because of the political usage that was made of them, directed at promoting and enhancing Italian nationalism - with the patriots of the Risorgimento first, and the Fascists after that.

The distance that we have now gained from those tragedies and their numerous interpretations have allowed us to look at them from a different perspective, one that enables us to uncover Alfieri's 'memories' behind his Agamennone and to finally account for the prominent role Alfieri has played in the Italian repertoire. The strength of Alfieri's tragedy lies in his ability to appropriate Aeschylus' Agamemnon and to make a new 'classic' work out of it; and it is Alfieri's Clytemnestra who will dominate operatic plays and re-writings of Aeschylus' Oresteia in the following centuries on the Italian stage. Indeed, Alfieri's 'remembrance' of Aeschylus, as mediated via Brumoy, allowed the survival of the Oresteia, and of the Agamemnon in particular, in an accessible form for almost a hundred and fifty years.

\section{Giovanna Di Martino}

University of Oxford

giovanna.dimartino@st-hildas.ox.ac.uk

37 Cf. T. Marrone, T., Oresteia, Rome, 1906. 